\title{
THE DEVELOPMENT OF MEDICINE AND HEALTH CARE IN PODILLIA IN THE XIX AT THE BEGINNING OF XX CENTURY
}

\author{
М. О. Сопіга, А. I. Машталір \\ ДВНЗ «Тернопільський державний медичний університет \\ імені І. Я. Горбачевського МОЗ Украӥни»
РОЗВИТОК МЕДИЦИНИ ТА ОХОРОНИ ЗДОРОВ’Я НА ПОДІЛЛІ У ХІХ - НА ПОЧАТКУ ХХ СТОЛІТТЯ

\begin{abstract}
The article is devoted to coverage of problems in medicine and health care in Podillia in 1793-1917 years. It is noted that in all corners of the Podillia region, the level of professional medicine in Podillia was extremely low. It was analyzed that in the vast majority of cases the medical aid was provided by charlatans and adventurers who shamelessly sold "miraculous medicines", and the initiators of medical sanitation on Podillia were mostly city and city dwellers. The article also analyzes the achievements and contributions to the medicine of Podillia of such scholars as Yakiv Postolovskyi, Prokip Danilevskyi, Edmund Fahrenholz, Joseph Rollie, Mykola Pyrohov, Danylo Zabolotnyi, Ludwig Malinowski, Mykola Boliarskyi and others.
\end{abstract}

Key words: medical aid; professional medicine; medical legislation; voivodship; paramedics; doctor of medicine; Podillia.

Анотація. Стаття присвячена висвітленню проблем медицини та охорони здоров’я на Поділлі в 1793-1917 рр. Відзначається, що у всіх куточках Поділля рівень професійної медицини був надзвичайно низьким. У статті проаналізовано, що в переважній більшості випадків медичну допомогу надавали шарлатани й авантюристи, які безсоромно продавали «чудові ліки», а ініціаторами медичної санітарії в Подільському регіоні були переважно міські жителі. У дослідженні також аналізуються досягнення і внесок у медицину Поділля таких вчених, як Яків Постоловський, Прокіп Данилевський, Едмунд Фаренгольц, Юзеф Роллє, Микола Пирогов, Данило Заболотний, Людвіг Маліновський, Микола Болярський та інші.

Ключові слова: медична допомога; професійна медицина; медичне законодавство; воєводство; фельдшер; доктор медицини; Поділля.

Introduction. From the end of the XVII and to the beginning of the XIX century, the level of professional medicine in Podillia was extremely low. In most cases, medical aid was provided by charlatans, adventurers, crooks, who shamelessly sold "miraculous drugs" and engaged in deception. Many people in a bitter experience were convinced of the lack of knowledge of the doctors of craft training and understood that their "treatment" only caused harm.

The first act of medical legislation in the Commonwealth, which included Podillia, which was aimed at creating a public health system, was the Constitution of 1775 . According to this law, a hospital should be organized in each voivodship, which would provide the

(c) M. O. Sopiha, A. I. Mashtalir population with inpatient treatment, trained paramedics and midwives for cities and villages, vaccination, and the fight against epidemics. However, due to lack of funds, these norms were abolished.

The aim - view the development of medicine and health care in Podillia in 1793-1917 years.

Theoretical framework. The initiators of sanitary facilities in the Commonwealth in the XVIII century were cities, as the city residents understood - from the implementation of medical-sanitary measures depends on their life, health and development of the city's industry. Therefore, in large cities in the first quarter of the XIX century, increasing attention was paid to their sanitary state. In Kamianets-Podilskyi, for example, the magistrate's decision was supposed to not pollute 
the streets with sweat, manure, corpses of animals, maintain purity in the bazaars. Magistrate Proskurov built a cemetery behind the city, which was covered with a deep moat [3].

The state of medical care in Vinnytsia was not one of the best. Here, residents used the services of people who did not have the appropriate knowledge too.

Thus, a bourgeois from the Old City, a witchhunter Zaika, who was also known outside Vinnytsia, was invited to the Braille town in 1770 to fight the outpouring. The methods of localization used by Zaika were quite original. He dug up the dead bodies of the victims and buried them on the border with the neighboring villages. It is clear that such measures contributed to its further expansion.

From the 70s, Marc Szepesel, a doctor of Botany and Chemistry, appeared in Bratslavshchina, who in official documents called himself a "doctor of medicine", which completely sounded like "a scientist doctor of medicine, different academies of trial”. In the 80's he settled down in Vinnytsia, opened the first pharmacy in the city and soon becomes quite famous .

However, the inhabitants of Vinnytsia and its suburbs are accustomed to seek medical assistance, according to their level of well-being, to various kinds of physicians, starting from such a "light" as Shepsel and ending with ordinary barberries. Worked and healers, but their services were mostly used by the poorer strata. Vinnytsia burghers repeatedly complained to the civil-military commission of Vinnytsia district and the Warsaw court for poor medical service.

The current educator in the field of education, the rector of the Main School in Krakow, Hugo Colontai, planned to send 120 guys from different cities (in 2 cities from each city) to the Main School and create a special bourse for them, and, for scholars, training, had to pay the city.

In the autumn of 1785, two Vinnytsia students were sent from Vinnytsia to Krakow and signed a solemn "commitment to return to the cities that sent them to study" in the Vinnytsia Act Book.

One of the scholars was Yakov Postolovskyi, son of an illiterate but wealthy burgher from the old city of Vasyl Pedchenko. Since his son was sent to Krakow, he changed his surname to Postolovskyi, believing that his son, Yakov Pedchenko, would not be able to study in Krakow and go to a doctor with such a non-aristocratic surname.

Of all the students of Vinnytsia alone, Yakov overcame the difficulties of medical science, which he received in 1792 a diploma. Physical College of Krakow University gave him a doctorate in medicine.
For almost four years, Postolovskyi stayed abroad to improve his knowledge and returned to Vinnytsia. For example, in the 70's of the XVIII century it became known in the autumn of 1795 . Townsmen immediately felt the difference between a barber and an educated physician, and moreover their fellow countryman.

Understanding the great wealth of the city is a true educated doctor, the Vinnytsia Magistracy greetly accepted his former scholarship and took care of providing him with a suitable accommodation at the expense of the city.

The story mentions another interesting person - the serf of Count I. Morkov from the village of Velyka Kukavka in the Mohyliv-Podilskyi district of the Podolsk province, named after Prokip Danilevskyi. In Count Morkov there were two extremely gifted serfs V. Tropinin and P. Danilevskyi. The first was the ability to draw, the second - the desire for knowledge. Graf sent to St. Petersburg Tropinin for painting education, and Danilevsky for medical education [3].

Prokip Danilevskyi, earning his living, successfully graduated from the Medical Faculty of Moscow University. There was a brilliant future in front of him, but the Count turned him to Kukavka. Prokip asked to let him go free, showing a diploma with honors, but Morkov broke the diploma with fury and sent the slave to the stables. Over time, Danilevskyi fled from the Count's court, he treated the sick serfs who hid him from the Count's servants, and then joined the detachment of Ustym Karmeliuk. Writer Vasyl Kucher in the novel "Ustym Karmeliuk" mentions a talented doctor-serf.

The future doctor of medicine, the well-known surgeon and social activist of Podillia Edmund Fedorovych Fahrenholz was born in KamianetsPodilskyi. He received his initial education in the Kamianets-Podilskyi gymnasium for men. In 1861 he entered the medical faculty of Kyiv University. He graduated from the St. Petersburg Medical Surgical Academy in 1868, where he was left for two years to improve his knowledge of surgery. In 1870 he successfully defended his doctoral thesis. For some time he worked as an assistant of professor M. V. Sklifosovskyi. In November 1878 Edmund Fedorovych moved to the Kamianets-Podilskyi Center of the Podolsk province. He was appointed a senior physician of the newly commissioned 150-bed hospital and, at the same time, the head of the surgical department. The talented physician developed a brilliant surgical activity here. He actively popularized the teachings of Lister at the meetings of the Society 
of Podolsk doctors, successfully used the Listerov method of treatment for operations on the organs of the abdominal cavity [3].

Due to the introduction of anti-fungal wounds treatment according to Lister, in the deep province the name of the modest surgeon of the Kamianets hospital soon became known far beyond the Southwest region of Russia. In the newspaper "Doctor" E. Fahrenholz in 1880 published an article entitled "From Kamianets Hospital”, in which he shared the clinical experience of using the Listeria bandage, and promoted the introduction of "counter-medication in county and city hospitals". The editorial board of the newspaper, which attracted a large number of doctors from different parts of the country to the scientific work, wrote about Fahrenholtz's notes: "We print an article by a great author as proof that Lister treatment is not only possible, but in fact it is becoming more and more alive in provincial hospitals".

From the statement of the medical case in the 80 years of the XIX century. Kamianets-Podilskyi hospital occupied one of the leading places among the district hospitals. This is a great achievement of the senior physician Fahrenholtz, a talented surgeon, who created a friendly team of assistants who subordinated all the personal interests of patients.

The talent of E. Fahrenholz was versatile. Everything new and advanced for his time, he tried to translate into practical work of the hospital, among doctors widely popularized the achievements of medical science.

In 1884, together with the progressive physician of Podolsk, the doctor of medicine J. Rollie, Fahrenholz took an active part in the organization and construction of a free hospital for the poor and conducted free consultations on surgical and outpatient surgery.

From 1895 until the end of his life (died in 1912), E. Fahrenholtz was in charge of the KamianetsPodilskyi children's shelter. He was the pioneer of the introduction of antiseptics in Ukraine in the 80 years of the XIX century. He took an active part in the work of the Society of Podolsk doctors, which became the ideological center of progressive doctors of the Southwestern region. At the meetings of the Society, he made about 20 scientific reports and held 43 demonstrations. In the medical environment Fahrenholz enjoyed exceptional authority. When the medical community of the province in March 1881 solved the question of who to elect a deputy on behalf of the Society of Podolsk doctors for the delivery of M. I. Pyrohov about the 50th anniversary of the work of the greeting address, then unanimously named the names of the doctor of medicine surgeon E. F. Fahrenholz and doctor of medicine obstetrician V. K. Zaderholm.

An important role in the study and development of medicine in Podillia was played by the son of a French emigre, a well-known public figure, Polish historianUkrainian scientist, writer, and doctor of medicine Joseph Rollie, known in historiography as Dr. Anthony or Jozef Anthony Apollinarius Rollie.

Joseph Rollie was born in 1830 in a picturesque area in Shargorodskoye Podolsk province. After the Kyiv Gymnasium, to choose the medical faculty of St. Volodymyr University to continue their studies. Almost a year he was trained as a nurse in the Kyiv hospitals, mainly in institutions for mentally ill. This practice identified his scientific profession and the profession of psychiatrist [2].

After graduating from the University, Joseph Rollie received a diploma with honors and began working as a doctor in the town of Yarishiv in Podillia. It was his first independent medical practice which formed him as a scientist in the field of medicine. He gave a lot of time to the treatment of patients of various states and soon gained respect and affection of the locals.

In order to improve his specialty in 1858, Joseph Rollie was a six-month internship for mentally ill in the town of Zonnenstein in Dresden. There he experimented, did experiments, preparing for a dissertation, took over the experience of German psychiatrists and established contacts with them.

In 1860, Rollie studied the practice of physicians in Paris for eight months and worked in the national library of France. On the basis of his own practice in Podillia, foreign clinics and the latest European treatment achievements, he graduated from the dissertation "Mental Illness" after his successful defense (1860). He received a doctor's degree in medicine.

Since 1861 J. J. Rollie forever settled in KamianetsPodilskyi, where he lived with his family for 33 years. It was the most successful in the scientific, literary and public life period of its activities. It is here that he achieves significant achievements in the field of medical education, where his becoming as a historian of Ukraine, ethnographer, and writer was taking place [2].

Rollie responded to medical practice as his main occupation, and from the very first days of his life in Kamianets-Podilskyi he successfully treated governors, officials, priests, wealthy Poles and Jews, school youth, the poorest of the city and the region. He spent a lot of time working in a city hospital, where he simultaneously put up medical experiments and introduced the most modern treatment methods. 
J.J. Rollie took an active part in the socio-political and scientific life of Podillia. After all, the city of Kamianets-Podilskyi in the middle of the XIX century became recognized as an important scientific center of Ukraine and beyond its borders in the field of medicine. The whole constellation of medical scientists and practitioners gathered here, among which there are well-known O. Kremer, A. Baranetsky, E. Fahrenholtz and others who initiated the creation of a scientific and public Society of Podilskyi doctors, which arose in 1859 and operated until the beginning of 1865 year. In 1861, Joseph Rollie joined the Society. The entire period of existence of the Society's constant head was known to the whole of Europe by a doctor, scientist, doctor of medicine Alexander Kremer, secretary since 1862 - Joseph Rollie [1].

According to the charter, the Society was interested in the course and development of medical sciences, the introduction of their achievements in practice, the study and improvement of the sanitary and hygienic status of the Podolsk province, the creation of a professional library and museum of local lore, providing financial assistance to doctors who lost their earnings by age or deterioration health, publishing activities. An important place was occupied by publications on the history of medicine and sanitary-and-hygienic life of the inhabitants of the region, which was mainly prepared by Rollie. In the 70's J. J. Rollie was the initiator of the establishment of a vaccine to minimize the spread of the epidemic of the disease, made a free vaccine for the poor, became the founder of midwifery courses, where he taught sanitation and hygiene, and became an active member of the established Mutual Assistance Society for the poor. [1, 2].

All Rollie's activities, his monographs, collections were aimed at establishing a healthy lifestyle, improving the state of health care, sanitary and hygienic and medical culture, improving living conditions and labor at work.

An important role in the development of medicine in Podillia was played by Mykola Ivanovych Pyrohov, who lived in the estate of Vyshnia, near Vinnytsia, in the last years of his life - from 1861 to 1881. An outstanding scientist, a brilliant surgeon, a founder of field surgery, a talented educator and a public figure in rural deafness proved the need, opportunity and effectiveness of providing medical care to the rural population. Being in close contact with the people, living in his interests, M. I. Pyrohov proposed a series of measures aimed at improving the medical care of the rural population [3]. By personal example, he showed how it is necessary to organize medical assistance. Then it was considered that for this purpose it is enough to allocate 2-3 medical assistants. However, M. I. Pyrohov, having built a small hospital, having opened a pharmacy, proved that the rural population also needs qualified medical aid. And this was an extraordinary event for the village. "The most happy results," the scientist noted, "I received from practice in my village: in 200 significant operations (amputations, resection, lithotomy, etc.), I did not observe any cases of traumatic rash, purulent festering and purulent infections in a year and a half, despite to the fact that the treatment after my operations I gave only forces of nature. "

The good results of treatment in rural settings, the doctor explained the placement of patients in peasant huts. However, an important role in the results of treatment played the organization of medical care. It is here, in difficult rural conditions, the scientist in practice proved his principle of the prominent role of the organization of medical care to the rural population. It was in Vyshnia that he proved the truthfulness of his views, which he later described in many works.

Nowadays the scientist's house has a memorial museum, which has acquired world-wide status for 60 years and has the status of a national one. During its existence it was visited by more than 7 million tourists.

One of the most famous names of immigrants from our region was and remains the name of the President of the All-Ukrainian Academy, the founder of the national epidemiology, a fighter with cholera and plague D. K. Zabolotnyi [3].

Danylo Kyryllovych was born in Chobotarka on Podillia (now Zabolotne village of Kryzhopil district). He studied at the Natural History Faculty of Novorossiisk University, worked in a bacteriological laboratory, organized by I. I. Mechnikov, under the influence of whom he decided to become a doctor. After graduating from the university he enrolled in the medical faculty of the Kyiv University, which graduated in 1894. Then he went to the city of Kamianets-Podilskyi, where he worked as a bacteriologist to combat the emergence of cholera and diphtheria, and establishes a bacteriological laboratory.

Next D. K. Zabolotnyi was testing anti-diphtheria serum, which was then first used in the treatment of diphtheria.

A year later, he returned to Kyiv. In 1896, a major epidemic of plague broke out in Bombay. He went there as a part of the Russian delegation. During the epidemic, while in the tropics, he collected valuable 
scientific material for the identification of plague pathogens, investigated and identified the ways of their penetration into the body and studied the course of the disease. Despite the difficulties, the scientist went to the place where the hearth of the epidemic erupted, which threatened people with danger.

After the epidemic in Bombay, D. K. Zabolotnyi went to study the plague in Arabia, where he led a scientific expedition to study and control the disease in remote regions of Russia, in the east of Asia, in China, Mongolia, traveled to Persia and Mesopotamia, exploring the causes of the plague in Transbaikalia and Manchuria [5].

A profound study and comparison of the natural environments and social conditions in which the disease arose and spread, enabled Zabolotnyi [4]. To make the ebullient epoch-making assumption that the carriers and spreaders of the plague are wild rodents.

As a result of the intense and purposeful work of Zabolotnyi and his students in the early 20-ies of the XX century. A scientific-pedagogical school was formed, which for the first time in Ukraine formed the definition of epidemiological science and the subject of teaching. New in the scientific works of the scientist and his school was the thought of the exclusive role of social factors in the development of the epidemiological process.

In 1927, D. K. Zabolotnyi wrote: "Epidemics are so profound in organizing society that they can fairly be regarded as a social phenomenon ...”. And he went on to say that "the spread of infectious disease in the masses is closely linked with social conditions, which are one of the most important epidemiological factors" [5].

D. K. Zabolotnyi and representatives of his school showed great interest in studying the historical experience of combating epidemics of severely infectious diseases. In a report at the IX Congress of bacteriologists, epidemiologists and medical doctors in 1925, the scientist noted that "the study of spontaneously occurring epidemics of past decades is required in order to correctly identify the means of struggle and achieve a reduction in morbidity". He saw the ultimate goal of epidemiology in the complete elimination of infectious diseases.

By attaching great importance to a scientifically proven organization of measures to combat epidemics, D. K. Zabolotnyi and representatives of his school stressed that ending with epidemics, it is necessary "to continue consolidating the anti-epidemiological front and go to active prevention”.
Being the founder of domestic epidemiological science and a major microbiologist, D. K. Zabolotnyi for 30 years (from 1898 to 1929) did not leave pedagogical science. He was the author of more than a hundred scientific works, closely linked scientific and pedagogical work with active social activities, initiated the opening of a medical institute in Vinnytsia. His tireless creative work as a fighter for the health of the people was highly appreciated. D. K. Zabolotnyi was elected a full member of the All-Ukrainian Academy of Sciences [5].

In the autumn of 1905 a graduate of the medical faculty of the University of Tartu (Tartu, Estonia) arrived in Vinnytsia, who already had a doctor's practice, 25-year-old L. I. Malinowski. Podilskyi region attracted him because he was born in the picturesque old town of Kamianets-Podilskyi.

Ludwig Ivanovich worked in the district hospital of Ushitsk district, and promoted his qualifications to Tartu, a city where he attended a professorial institute and worked at the university as an outstanding scientist M. I. Pyrohov. Now the fate corrects the life of Malinowski so that he comes to the city where lived, worked and forever remained to rest M. I. Pyrohov. He was appointed by the surgeon and senior physician of the Zemstvo Hospital. The fruitful period of the young doctor's work began. The hospital, where he was assigned, was overcrowded and demanded an immediate repair, which will go on for a long time. In buildings, designed for 75 beds, constantly placed 125130. Ludwig Ivanovich was fully committed to work, forgetting about the rest. At the level of modern scientific medicine, he put up a medical case. At the same time he was engaged in the improvement of the hospital.

In November 1910, the 100th anniversary of the birth of M. I. Pyrohov in Vinnytsia, a congress of the AllRussian Surgical Pyrohov Society took place, where, on the proposal of a member of the Vinnytsia Pyrohov Society L. I. Malinowski received permission to build a hospital in the city named after M. I. Pyrohov, as honoring the memory of the scientist, and announced the collection of funds. Under construction, the city administration has allocated a land plot. A memorable sign - a large granite stone with a sculptural bust of a brilliant scientist - was installed on the site of the future surgical hospital. However, due to lack of funds, the construction of the hospital continued slowly [6].

April 23, 1917 was consecrated Pyrohov hospital, but the opening was postponed. Suddenly ill Malinowski, who had to open the door of his long-awaited dream, and patients of the Zemsky hospital had to be 
transferred to Pyrohov hospital. However, not destined L. I. Malinowski feel the joy of a long-awaited event. In two weeks he died. Senior provincial hospital doctor, senior doctor military hospital during the First World War, one of the leading surgeons skirts, author of five scientific papers on surgery, the head of the Vinnytsia Medical Society, one of the founders of the Pyrohov hospital - that appeared L. I. Malinowski for incomplete 12 years of work in Vinnytsia.

Among the figures of domestic medicine, who played an important role in the development of medical science, a significant place belongs to Mykola Mykolaiovych Boliarskyi. Studying at the Medical Faculty of the University of Dorpat, M. Boliarskyi transferred to the St. Petersburg Military Medical Academy, which graduated well in 1905, and in 1910, at the Academy, she defended the dissertation brilliantly [6].

The Obukhiv Hospital in St. Petersburg was the school of many well-known surgeons and formed doctors of various directions. It was this hospital that trained in Mykola Mykolaiovych's love for scientific and practical activity. It was here that 7 years of persistent practical work along with systematic study of domestic and foreign literature gave him the opportunity to become a versatile educated and recognized surgeon not only in St. Petersburg, but also far beyond its borders. He was attracted to practical activity on the periphery, the desire to carry his knowledge, skills and assistance to the people. Therefore, after demobilization of the army (1917), the doctor of medical sciences, an active member of the St. Petersburg Pyrohov Society, having the opportunity and the invitation to return to St. Petersburg, accepts the proposal of the Vinnytsia Zemstvo Council. M. M. Boliarskyi was appointed chief physician and chief surgeon of the Vinnytsia Pyrohov Hospital, which had not been opened by Ludwig Malinowski, where he worked 22 years before his last days. In the past, zemstvo doctor, imitating the principles of rural medicine, he easily learned the preventive direction of health and implemented it [3].

Surgical activity of Boliarskyi was struck by the harmony, strict style, precise and accurate execution of operations. His exceptional dedication and demandingness combined with softness and cordial attitude to the sick.

Highly educated, thoughtful and sensitive doctor, Mykola Mykolaiovych very quickly won the trust and love of the population. Due to the high qualification and authority of Boliarsky, the Pyrohov Hospital became an exemplary medical institution.
M. M. Boliarskyi was a talented clinician surgeon. He possessed high technology and brilliantly performed various and complex surgical interventions, from operations of the abdominal cavity and ending with operations on the heart and brain. During his work, the surgeon made about 35 thousand surgical interventions. Mykolai Mykolaiovych is one of the domestic pioneers of cardiovascular surgery, studied appendicitis, peritonitis, urology, developed the questions of traumatology, offered a system of prevention. All questions of interest to him were covered in his scientific works. He was a wonderful teacher, constantly trying to convey his knowledge to his disciples. His lectures, reproducing the latest achievements of medicine, differed in their deep meaning and, at the same time, extraordinary clarity and simplicity. Great attention among doctors and students was used by his clinical outings and outpatient receptions.

The name of Boliarskyi is closely connected with Vinnytsia Medical University. He was one of the initiators and organizers and headed the Department of Faculty Surgery. He had done a lot for equipping his own and other clinics, creating a laboratory, organizing scientific work for the growth of doctors and training specialists.

Generally recognized merit of M. M. Boliarskyi is his initiative and active participation in the work on preserving the body of M. I. Pyrohov [3]. At the First Ukrainian Congress of Surgeons in 1926, on the initiative of M. Boliarskyi and his teacher I. I. Trekova created a special commission, on whose proposal were made necessary measures, through which the embalmed body of a brilliant scientist could persist in the future.

Conclusions and Prospects for Research. Time tirelessly goes forward. Modern doctors of Podillia, based on the discovery and experience of predecessors, are the successors, innovators and pioneer in various branches of medical science, they enrich it with their discoveries, inventions of great importance and original methods of examination and treatment of patients.

Medical figures of Podillia of the 19th of the beginning of the 20th century marked the beginning of modern medicine and health care of Ukraine. Thanks to their achievements, there is a progressive development of modern medicine and health care in general. In the future, it is quite important to investigate the impact of health professionals, individuals directly involved in medicine, health care and health care facilities in Right-Bank Ukraine in the XIX and early XX centuries, including in Podillia. 


\section{List of literature}

1. Баженова С. Е. Юзеф Антоній Роллє: життя, діяльність, творчість : монографія / С. Е. Баженова. - 2-ге вид., доповн. - Кам'янець-Подільський : Кам'янецьПодільський державний університет, інформаційно-видавничий відділ, 2002. - 180 с.

2. Баженова С. Е. Юзеф Роллє і Україна : монографія / С. Е. Баженова. - Кам’янець-Подільський : Сисин Я. І., 2016. - 200 c.

3. Вчені Поділля (фундаментальні наукові праці) : матеріали Респ. наук.-практ. конф., присвяч. 55-річ-

\section{References}

1. Bazhenova, S.E. (2002). Yuzef Antonii Rollie: zhyttia, diialnist, tvorchist: monohrafiia [Joseph Antony Rollie: life, activity, creativity: Monograph]. Kamianets-Podilskyi: Kamianets-Podilskyi State University, Information and Publishing Department [in Ukrainian].

2. Bazhenova, S.E. (2016). Yuzef Rollie i Ukraina: monohrafiia [Joseph Rollie and Ukraine: Monograph]. Kamianets-Podilskyi: Sysyn Ya.I. [in Ukrainian].

3. Neiko, Ye.M. (1999). Vcheni Podillia (fundamentalni naukovi pratsi) [Podillia Scientists (basic scientific works)]. Materialy resp. nauk. prakt. konf. prysviach. 55-ricchiu vyzvolennia Ukrainy vis fashyst. Zaharbnykiv - Materials чю визволення України від фашист. загарбників / ред. $€$. М. Нейко ; Вінницький державний медичний університет імені М. І. Пирогова. - Хмельницький; Вінниця : Поділля, 1999. - Ч. 1. - 349 с.

4. Заболотний Д. К. Завдання чумних обстежень / Д. К. Заболотный // Профілактична медицина. - 1925. № 12.

5. Заболотный Д. К. Избранные труды / Д. К. Заболотный. - К. : Академия наук УССР, 1957. - Т. 2. - 321 с. 6. Пирогов М. І. Зібрання творів : у 5 т. / М. І. Пирогов. - М., 1961. - Т. 1. - 370 с.

of the Republican Scient.-pract. Conf. devoted to the 55th Anniversary of Liberation of Ukraine from Fascist Invaders. Vinnytsia State Medical University named after M. I. Pyrohov. Khmelnytskyi; Vinnytsia: Podillia [in Ukrainian].

4. Zabolotnyi, D.K. (1925). Zavdannia chumnykh obstezhen [Tasks of plague surveys]. Profilaktychna medytsynaPreventive Medicine, 12, 227 [in Ukrainian].

5. Zabolotnyy, D.K. (1957). Izbranyye trudy [Selected Works]. Kyiv: USSR Academy of Sciences [in Russian].

6. Pyrohov, M.I. (1961). Zibrannia tvoriv [Collected Works]. Moscow [in Ukrainian]. 